\title{
Students Learning Outcomes and Internalization Islamic Values in Buffer Solution Concept through Online Learning
}

\author{
Leny Heliawati ${ }^{{ }^{*}}$, Anna Permanasari ${ }^{1}$, and Uun Sundari ${ }^{1,2}$ \\ ${ }^{1}$ Department of Science Education Education, Graduate School, Universitas Pakuan, \\ Jl. Pakuan, RT.02/RW.06, Bogor Tengah, Kota Bogor, 16129, Indonesia \\ 2SMAIT Insantama, Jl. Hegarmanah IV No.47, Bogor Barat, Kota Bogor, 16118, Indonesia \\ "E-mail: leny_heliawati@yahoo.co.id
}

Received: 25 May 2021; Accepted: 18 June 2021; Published: 30 June 2021

\begin{abstract}
This study analyses students learning outcomes and internalization of Islamic values in buffer solutions through online learning during the Covid-19 pandemic. The study was conducted to find effective strategies in achieving students' competence and Islamic values. This research is a quasi-experimental study conducted on 100 tenth-grade students using The One Group Pretest-Posttest model. The results showed students learning outcomes obtain an N-Gain value of 0.72 (high category). The internalization of Islamic values for three aspects: praying, blessing, and study hard determined the average above 3 (often do). Thus, the research concludes that online learning conducted on buffer materials is effective in mastering the content and internalization of Islamic values.
\end{abstract}

Keywords: buffer solution, concept mastery, online learning, Islamic values

DOI: https://doi.org/10.15575/jtk.v6i1.12642

\section{Introduction}

The Coronavirus Disease (Covid-19) pandemic has become the world's first and foremost health crisis today. This pandemic has spread to various countries, including Indonesia. This requires a variety of efforts to prevent transmission through broader adjustment and attitude taking from various sectors, including the education sector. As of May, UNESCO (2020) recorded as many as $1,268,164,088$ students or $72.4 \%$ of the total students enrolled worldwide were affected by this pandemic. Even though a recent modeling study from Covid-19 predicts that school closure will only prevent $2-4 \%$ of deaths, far less than other social distance interventions (Viner et al., 2020; Esposito \& Principi, 2020; Bayham \& Fenichel, 2020). The fact is that various countries do not want to take risks and continue to close schools. The World Bank Education Global Practice (2020) records there has been temporary closure of schools in more than 160 countries. School closures that are still being extended can cause a loss of learning in the short term. More than that, if it continues, this condition will adversely affect the quality of human resources and economic opportunities in the long run.

The impact of the pandemic on how to study in Indonesia following the regulations of the Ministry of Education and Culture has determined the Implementation of Education Policy in the Emergency Period of the Outbreak of Covid-19. One step is about the instruction of the learning process from home. Home learning policies are applied to all levels of education, from preschool to colleges, both public and private. In Indonesia, home learning policy has been carried out by around 28.6 million students from elementary school to high school/vocational school. In addition, a total of 279 state and private colleges have 
implemented online lectures. The learning process from this house has been going on since the beginning of the pandemic and is still being extended following the development of the situation (Arifa, 2020). This requires adjustments to the learning strategy during the Covid-19 pandemic so that the learning process continues to be effective even if it is done from home.

The learning process challenges from home include human resources; not all educators and students ready to face distance learning online. Especially for educational institutions in remote areas, with limited facilities both in terms of devices and networks, of course, are still far from ready (Arifa, 2020; Allo, 2020; Zhang et al., 2020). Students and educators have felt various negative impacts during the learning process from home. At the same time, the success of learning is determined by the knowledge and cooperation of educators in meeting students' learning needs (DarlingHammond et al., 2020). During learning from home, students feel forced to study distance without adequate facilities and infrastructure. The culture of distance learning is not yet formed, so it takes time to adapt to change. The long absence of school activities with all their interactions has the opportunity to increase the level of boredom (Purwanto et al., 2020). However, meaningful interactions have a positive correlation to one's self-esteem either through digital or face-to-face interaction. However, the effects of face-toface interactions are more durable than digital interactions (Subrahmanyam et al., 2020). A similar impact is also felt in terms of educators. Not all educators can take advantage of supporting devices for online learning activities. Teacher competence in using technology can affect the quality of online learning carried out during the study period from home. The absence of a culture of distance teaching causes educators to adapt, especially to the boredom of the situation due to limited communication and interaction with students.

Various limitations that occur as an impact experienced by students can affect the comprehension of learning. In general, the impact of a pandemic experienced by education practitioners can affect online learning quality. In the long run, this will affect the quality of education that is formed. This is certainly not expected. Ideally, even during the learning process from home in the middle of a pandemic, the expected educational goals must still be considered. The National Education System Law No. 20 of 2003 has mandated national education to develop the potential of students to become human beings who believe and fear God Almighty, noble, healthy, knowledgeable, capable, creative, independent, and become citizens democratic and responsible. The purpose of this education is then broken down into four core competencies that students must achieve, namely attitude competencies both in spiritual and social, knowledge competencies, and skills. The attainment level of attitude competence is divided into five levels of attitude: accepting values, responding to values, comprehending values fully, living values, and practicing values by developing them as characteristics in thinking, saying, communicating, and acting (Kemdikbud, 2014).

The process of learning from home with all its challenges still must pay attention to the achievement of students' competencies that have been set. Unfortunately, in the process of instilling spiritual values, teacher lectures in Islamic schools still focus on mastering content in the sense of pursuing knowledge competencies compared to other competencies (Imaduddin, 2019). Though, the achievement of spiritual competence is no less important and very necessary. Learning that has a divine value has an important role in preparing a generation of higher quality who masters science and technology with good morals. Even in a democratic environment, where spirituality talks are taboo in American public school classrooms when equating spirituality with ontology, there is the awareness that it is impossible to avoid teaching spirituality in American schools (Thayer-Bacon, 2016). Hiatt (2016) shows at Brigham Yaoung University; students are more interested in handling spirituality in the classroom. This study examines the extent to 
which teachers can meet students' demands to pay greater attention to spirituality in the classroom without compromising accuracy and learning.

This study analyses online learning approaches in buffer solution materials during a pandemic in achieving students' knowledge and spiritual attitude competencies. Knowledge competency is measured based on student learning outcomes. The challenge in achieving students' knowledge competency is the ability of students to understand abstract and unknown chemical concepts (Treagust \& Chittleborough, 2001). The buffer solution is an abstract and conceptual chemical material, although the role of the buffer solution is real and can be applied (Arnas, 2012). Teacher explanations of material often use various molecular formulas, chemical equations, and various processes at the microscopic level that are difficult for students to understand (Setiadi \& Irhasyuarna, 2017). Students who have difficulty in abstract thinking cannot achieve optimal learning outcomes (Drastisianti, 2019). Therefore, various forms of representation that can help visualize the buffer solution material are needed to be studied easily.

Various ways to improve the understanding of buffer solution materials have been carried out, showed by Sari and Ulya (2017) using pop-up books in explaining the role of buffer solutions in the body of living things. Amalina et al. (2018) and Yani et al. (2019) use guided inquiry-based student worksheets to efforts in mastering student content on buffer materials. Cahyana et al. (2019) also develop mobile game-based learning on buffer solution materials. In addition to improving mastery of the material, various learning approaches to buffer solutions are also carried out to improve students' various skills and characters. Among them are the use of TaskBased learning to improve generic science skills (Pitasari \& Yunaningsih, 2016), improvement of science process skills through process-oriented guided inquiry learning (Firmansyah \& Khumaidah, 2017), and the development of values-laden questions to strengthen student character (Sulastri et al.,
2018). These learning approaches are carried out directly in the classroom with the teacher's assistance. Therefore, the analysis of an online learning approach in this pandemic period needs to be studied.

This study analyses the inculcation of students' spiritual attitudes. This spiritual attitude is important to analyse because the Covid-19 pandemic situation has the potential for mental stress for students with the demands of the home learning situation for a long time. Spiritual attitude is usually associated with spiritual conditions associated with the power of God Almighty or religion (Wiguna, 2017). The spiritual attitude competencies listed in the 2013 Curriculum are the ability to appreciate, comprehend, and practice the teachings of the religion professed by students. Indicators of spiritual attitude competency achievement include observance of worship, gratitude, praying before and after activities, and tolerance in worship (Januarti et al., 2017). Indicators in this spiritual attitude can develop following the policies of the education unit. The spiritual attitude in this study is limited to three indicators, namely praying when starting and ending learning, being grateful for the blessings given, and serious learning as a form of gratitude. This research is expected to find effective learning strategies in the learning process from home during the pandemic. An online learning approach that still pays attention to attaining knowledge competencies through mastering content and instilling students' spiritual attitudes so that educational goals are still achieved even in pandemic conditions.

\section{Research Method}

This research is a quasi-experimental study. The sample consisted of 100 students who were in $11^{\text {th }}$ grade. In a quasi-experimental study, the sample is not placed specifically in a particular group but is left without randomization (Hastjarjo, 2019). The design group taken in this study is one of the quasiexperimental design groups by Shadish et al. (2002), a design without a control group with the type of design of one group pre-treatment 
and post-treatment (The One Group PretestPosttest). One study using this method was conducted by Yang and Lin (2010) regarding the effect of interactive cell phones and software on students' perceptions and effectiveness. The effect of a treatment is decided based on the difference between pretest and posttest.

The quasi-experimental method was chosen given the adjustment of learning time during the pandemic period, reducing the students' learning burden from home. However, while learning to achieve the target of concept mastery in teaching materials must still be done. Besides, research is also conducted following the theme of ongoing lessons so that the selection of this method will not interfere with the learning process but is considered to support learning objectives following the intended research objectives. The model chart used is shown in Table 1.

Table 1. Model Chart of The One Group Pretest and Posttest

\begin{tabular}{ccc}
\hline Pretest & Treatment & Posttest \\
\hline $\mathrm{T} 1$ & $\mathrm{X}$ & $\mathrm{T} 2$ \\
\hline
\end{tabular}

$\mathrm{T} 1$ is a pretest conducted before the study sample is given treatment, while $\mathrm{T} 2$ is a posttest conducted after the sample is given treatment. $\mathrm{X}$ is an online learning process. The treatment in the form of online learning is meant by using WhatsApp Group media and other supporting media in textbooks with Islamic internalization and learning videos containing related material.

In this study design, the experimental and control groups are the same class, with the same type of material. The first period of online learning is done through material explanations and discussion in the form of text in the WhatsApp group, supplemented by video learning links that are self-studied by students. After online learning, the first period was given 20 multiple choice questions as a pretest regarding buffer solutions ranging from definition to application in life worked through Google Form. In online learning, the next period of learning is complemented by using teaching materials with Islamic internalization. The questions in the posttest are 20 multiple choice questions with a kind of pretest material with the addition of Islamic narrative stimulants in part. After completing the pretest and posttest, the average score of the achievement (gain) is calculated and compared to determine the effectiveness of the done treatment. Analysis of student learning outcomes is done by calculating the score of $\mathrm{N}$-gain. $\mathrm{N}$-gain is used to measure the difference between the pretest and posttest scores. Competency improvement that occurs before and after learning is calculated with the following formula:

$$
\mathrm{N}-\text { gain }=\frac{\text { Spost }- \text { Spre }}{\text { Smaks-Spre }}(1)
$$

Spost is a score obtained by students at the posttest, while Spre is a score obtained by students at the time of a pretest. The difference between the posttest and pretest scores compared to the Smaks difference (maximum score set) with the pretest scores will result in an $\mathrm{N}$-gain score. The N-Gain interpretation is presented in Table 2.

Table 2. Classification of $\mathbf{N}$-Gain Interpretation

\begin{tabular}{cc}
\hline Percentage Range & Interpretation \\
\hline $\mathrm{g}>0,7$ & High \\
$0,3<\mathrm{g}<0,7$ & Medium \\
$\mathrm{g}<0,3$ & Low \\
\hline
\end{tabular}

Attitudes are behaviors that are seen in students. Spiritual attitude assessment assesses the attitude on the spiritual aspects instilled by the teacher and seen in students (Saidah \& Damariswara, 2017). Attitude assessment can be done through observation, interviews, and peer assessment questionnaires or self-assessment. The students' spiritual attitude in this study was assessed through a self-assessment sheet. Self-assessment is carried out during the learning process from home in online class groups through filling in the form at the end of the learning period. The reference used in determining the level of success of achieving students' spiritual attitude competencies is done through scoring guidelines in the rubric of self-assessment. The scoring guide is used as a guide that explains the keywords in terms 
of the statement given. Attitude statements contain positive things about attitude objects, using sentences that support the attitude objects. The scoring guide in the selfassessment rubric is carried out on a scale of 1 to 4 . Students give a score of 4 for statements about behavior that are assessed as always being done. Students give a score of 3 to statements about behavior that are judged to be done frequently. If students feel that they only occasionally perform the behavior contained in the statement, then students give a score of 2. Meanwhile, if students feel they have never done the behavior contained in the statement, then given a score of 1 .

The process of presenting data is carried out on three indicators of spiritual attitude measured, namely praying when starting and ending learning, grateful for the favors given, and learning seriously as a form of gratitude, in the form of tables. A brief description of each indicator is based on the scoring results and is described following the average score on each achievement of the observed spiritual attitude indicators. After the data presentation, the verification process is carried out by concluding various data analyses carried out.

\section{Result and Discussion}

Online learning of buffer solution materials is carried out during two meeting periods by utilizing the WhatsApp group, video supporting material, and textbooks with Islamic internalization. Textbooks with Islamic internalization are used to support the understanding of chemical solution materials with the explanation and closest example in the environment and reinforce the attainment of students' spiritual attitudes.

An assessment of the effectiveness of online learning is done through pretest and posttest for sample classes. The questions consist of 20 items with various cognitive levels. The score of students' learning outcomes in the pretest and posttest can be seen in Figure 1 and Table 2.

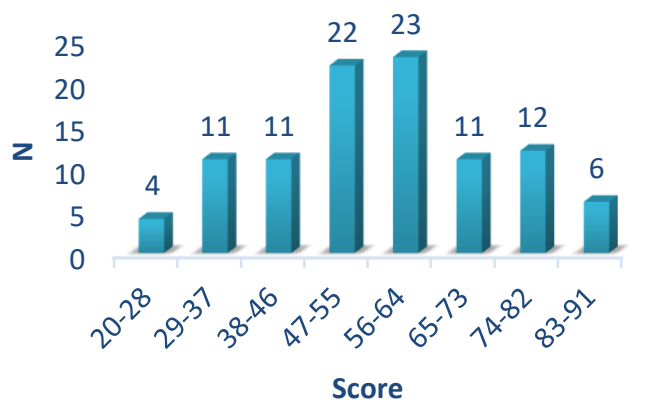

(a)

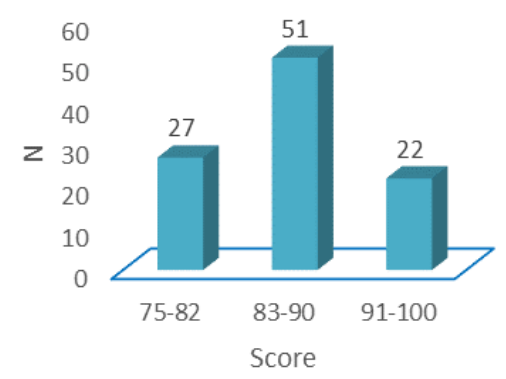

(b)

Figure 1 shows the distribution of students' learning outcomes in the pretest (a) and posttest (b). The range of student scores at the pretest time is still very broad, between 20 and 90. While the results of the posttest, the range of scores narrows between 75 and 100 .

Table 3. Students' Learning Outcomes

\begin{tabular}{lcccc}
\hline \multicolumn{1}{c}{ Test } & $\mathbf{N}$ & $\begin{array}{c}\text { Lowest } \\
\text { score }\end{array}$ & $\begin{array}{c}\text { Highest } \\
\text { score }\end{array}$ & Mean \\
\hline Pretest & 100 & 20 & 90 & 57 \\
Posttest & 100 & 75 & 100 & 87 \\
\hline
\end{tabular}

Based on Table 3, the pretest and posttest activities have increased in the lowest score, the highest score, and the mean. All students' scores on the posttest had passed the minimum criteria of mastery learning of 75 . At the same time, the $\mathrm{N}$-gain test was conducted to see whether online learning while learning from home could improve students' learning outcomes. The $\mathrm{N}$-gain score of students' learning outcomes is presented in Table 4. 
Table 4. N-gain Score

\begin{tabular}{|c|c|c|c|c|}
\hline & $\begin{array}{l}\text { The } \\
\text { average } \\
\text { of the } \\
\text { posttest } \\
\text { score - } \\
\text { pretest } \\
\text { score }\end{array}$ & $\begin{array}{l}\text { The } \\
\text { average } \\
\text { of the } \\
\text { maximum } \\
\text { score - } \\
\text { pretest } \\
\text { score }\end{array}$ & $\begin{array}{l}\mathbf{N}- \\
\text { gain }\end{array}$ & Criteria \\
\hline $\begin{array}{l}\text { Tested } \\
\text { class }\end{array}$ & 30.30 & 43.40 & 0.72 & High \\
\hline
\end{tabular}

Based on Table 4, the N-gain score obtained is equal to 0.72 . This score is in the high criteria. This means online learning using the help of learning videos and textbooks to internalize Islam during the learning process from home is considered effective. However, the N-Gain score produced is not far from the medium criteria, equal to 0.70 . This shows that there are still challenges in increasing the effectiveness of online learning in the learning process from home during the pandemic.

The success of online learning during the pandemic period was also carried out towards instilling students' spiritual attitudes. The results of the assessment of the inculcation of the value of spiritual attitudes are set out in Table 5.

Table 5. Assessment on the inculcation of the value of spiritual attitudes

\begin{tabular}{llc}
\hline No & \multicolumn{1}{c}{ Spiritual aspects } & $\begin{array}{c}\text { The } \\
\text { average } \\
\text { score }\end{array}$ \\
\hline $1 . \quad \begin{array}{l}\text { Pray when starting and } \\
\text { ending learning }\end{array}$ & 3.58 \\
2. $\quad \begin{array}{l}\text { Be grateful for the blessings } \\
\text { given }\end{array}$ & 3.58 \\
3. $\quad \begin{array}{l}\text { Learn seriously as a form of } \\
\text { gratitude }\end{array}$ & 3.38 \\
\hline
\end{tabular}

Based on table 5, the inculcation of spiritual values continues to run well while learning from home during the pandemic. It shown by the average score that is above three, where students often do the activity intended.

During the pandemic, learning in schools was adjusted by being diverted to online learning. International Baccalaureate (2020) states various strategies commonly used in online activities can be done through blogging and vlogging, writing, or making collaborative stories, spreadsheets, text-based discussion forums, e-portfolios, gamification, online teaching, live video discussion, multimedia presentations and video conferencing. Online learning strategies are chosen according to the conditions and effectiveness of learning in each education unit. For example, to utilise text-based discussion forums, chemistry learning in buffer solution materials is done through online learning forums, WhatsApp Group.

The online learning process is carried out through a scientific approach by following the five steps in the approach include observing, questioning, experimenting, reasoning or associating, and communicating. Video supporting material and the use of textbooks are done in observing and gathering information or experimenting. Technically, after the teacher opens a lesson in an online class group and students do an attendance checklist, the learning process begins. Learning from home does not require a long time, namely only at the first-period meeting for high school students to adapt to the new learning techniques through online learning. This is in line with what was discovered by Basilaia and Kvavadze (2020), where the Google Meet platform was implemented for online education in private schools with 950 students in Georgia, confirming that the transition to online education in the pandemic period was rapid and successful. The speed of adaptation ability of educators and students is a crucial part of the current transition conditions. If it is properly utilized, this shift will be beneficial for integrating educational technology in the future (Sandars et al., 2020; Zhou et al., 2020; Narine \& Meier, 2020).

Many factors influence effectiveness during online learning. Bao (2020) presents his findings on the effectiveness of online learning practices during the pandemic at Peking University. The first is to relevance that the quantity, difficulty, and duration of teaching must be following academic readiness and the characteristics of students' online learning behavior. The second is the principle of the effectiveness of the material delivery. With all the negative effects of the 
pandemic, especially on the students' psychological sides, it can reduce the level of students' concentration during online learning. Therefore, adjustments in teaching speed are needed to ensure the effective delivery of information. The next principle is related to support, that teachers need to provide feedback to students at the right time. Finally, quality participation from students determines the effectiveness of online learning. Increasing student participation can be done by taking more fun learning variations to be done by students. Fun learning variations proven to make students more active and creative include using picture storybooks (Atiqoh \& Prasetyo, 2018) and digital science storytelling (Dewi et al., 2019). In addition, student anxiety needs to be reduced in various ways to ensure that students can be actively and effectively involved in online learning.

The spiritual attitude listed in the first core competency in the 2013 Curriculum is in the form of appreciation and practice of religious teachings. This competency is developed to be an indicator of learning achievement. Spiritual attitudes that can be formed through the integration of science and religion require support for using the right language, scientific literacy, and the right methods (Nasir et al., 2020). Johan et al. (2018) have succeeded in increasing students' concept mastery and spiritual attitudes in the study of earth science with the help of authentic visualization and data from GrADS. This study raised three indicators of spiritual attitudes modified from the indicators set by the Ministry of Education and Culture, namely praying when starting and ending learning, being grateful for the blessings given, and learning seriously as a form of gratitude. Praying when starting and ending learning has a high average score because the teacher always helps remind and invite students to pray to accompany the learning process during face-to-face learning in class and during online learning. This causes students to become more accustomed to this prayer activity during the online learning period.
The results of online learning also show the achievement of aspects of being grateful for the favors given to students is also high. The general condition of the pandemic is admitted students to help increase awareness of the favors that have been given and more grateful for it. Even though the learning process is done online, it can still be followed well. This is a blessing that every student cannot feel who is limited in providing online facilities. One form of gratitude is shown in learning seriously. The average score of practicing gratitude in the form of a deed by studying hard is still lower than the extent of being grateful for the favors given. Behind all the negative impacts caused, the Covid-19 pandemic increases religious awareness in society (Saebani, 2020; Kuswana et al., 2020; Siregar et al., 2020). Textbooks assist the ability to link scientific material with spiritual aspects with Islamic internalization that contains verses of the Koran related to teaching materials, as well as helping to connect natural phenomena that occur, including buffering solutions with God's power. Awareness that can be presented in linking science material and natural phenomena with God's power, in the long run, can encourage the formation of individuals who practice this awareness in the form of loyalty to the religious rules they profess.

\section{Conclusion}

Based on the research, it can be concluded that online learning during the period of learning from home in the pandemic on buffer solution materials can run effectively. This effectiveness is seen based on the students' content mastery as indicated by the N-Gain score from the sample class equal to 0.72 (high category). Even though it has been considered effective, the online learning process still needs improvement to enhance further students' involvement in a more enjoyable online learning process. Meanwhile, the inculcation of the value of spiritual attitudes continues during lea rning from home. This can be seen based on the average score of three aspects determined to be above 3 , which means they often do. Therefore, the Covid-19 pandemic demands innovative home study 
Students Learning Outcomes and Internalization Islamic Values in Buffer Solution Concept through Online Learning

strategies so that students can still learn effectively, especially for Islamic-based schools. The spiritual attitude of students becomes an integrated part that cannot be separated even when studying at home.

\section{References}

Allo, M. D. G. (2020). Is the online learning good in the midst of Covid-19 pandemic? The case of EFL learners. Jurnal Sinestesis, 10(1), 1-11. Retrieved from

https://sinestesia.pustaka.my.id/journal/ article/view/24

Amalina, N. S., Wardani, S., \& Wijayati, N. (2018). Pembelajaran guided inquiry berbantuan lembar kerja siswa untuk meningkatkan hasil belajar siswa. JTK: Jurnal Tadris Kimiya, 3(1), 1-10. https://doi.org/10.15575/jtk.v3i1.2254

Arifa, F. N. (2020). Tantangan Pelaksanaan Kebijakan Belajar dari rumah dalam masa darurat Covid-19. Info Singkat: Kajian Singkat terhadap Isu Aktual dan Strategis, 12(7), 13-18. Retrieved from http://berkas.dpr.go.id/puslit/files/info_ singkat/Info\%20Singkat-XII-7-I-P3DIApril-2020-1953.pdf

Arnas, E. A. J. (2012). Pengaruh penggunaan laboratorium virtual dan laboratorium real terhadap sikap ilmiah dan hasil belajar kimia siswa SMA pada pokok bahasan larutan penyangga. Thesis, Program Pascasarjana: Universitas Negeri Medan.

Atiqoh, N. \& Prasetyo, Z. K. (2018). The effect of picture storybook based on scientific approach through inquiry method toward student's inference skill. Journal of Turkish Science Education, 15, 22-32. Retrieved from https://tused.org/index.php/tused/articl e/view/685/587

Bao, W. (2020). Covid-19 and online teaching in higher education: A case study of Peking University. Human Behavior and
Emerging Technologies, 2(2), 113-115. https://doi.org/10.1002/hbe2.191

Basilaia, G., \& Kvavadze, D. (2020). Transition to online education in schools during a SARS-CoV-2 Coronavirus (Covid-19) Pandemic in Georgia. Pedagogical Research, 5(4), 1-9. Retrieved from https://eric.ed.gov/?id=EJ1263561

Bayham, J., \& Fenichel, E. P. (2020). Impact of school closures for Covid-19 on the US health-care workforce and net mortality: a modelling study. The Lancet Public Health, 5(5), 271-278. https://doi.org/10.1016/S24682667(20)30082-7.

Cahyana, U., Paristiowati, M., Pratiwi, W. E., \& Zahari, P. A. (2019). Development of mobile game base learning on buffer solution to improve student performance. Journal of Physics: Conference Series, 1402(5), 055063. https://doi.org/10.1088/17426596/1402/5/055063

Darling-Hammond, L., Flook, L., Cook-Harvey, C., Barron, B., \& Osher, D. (2020). Implications for educational practice of thescience of learning and development. Applied Developmental Science, 24(2), 97-140. https://doi.org/10.1080/10888691.2018. 1537791

Dewi, N. R., Magfiroh, L., Nurkhalisa, \& Dwijayanti, I. (2019). The development of contextual-based science digital storytelling teaching materials to improve students' critical thinking on classification theme. Journal of Turkish Science Education, 16(3), 364-378. Retrieved from http://www.tused.org/index.php/tused/ article/view/80

Drastisianti, A., Susilaningsih, E., Wijayati, N., Nada, E. I., \& Alawiyah, N. (2019). Analysis of student concept understanding on the material of buffer solution using three-tier test assisted by 
Students Learning Outcomes and Internalization Islamic Values in Buffer Solution Concept through Online Learning

multiple representation teaching materials. Journal of Physics: Conference Series, $\quad 1321(2), \quad 022050$. https://doi.org/10.1088/17426596/1321/2/022050

Esposito, S., \& Principi, N. (2020). School closure during the coronavirus disease 2019 (Covid-19) pandemic: An effective intervention at the global level? JAMA pediatrics, 174(10), 921-922. https://doi.org/10.1001/jamapediatrics. 2020.1892

Firmansyah, R. A. \& Khumaidah, U. (2017). Kualitas keterampilan proses sains siswa yang terbiasa teacher-centered learning melalui process oriented guided inquiry learning. JTK: Jurnal Tadris Kimiya, 2(2), 130-144.

https://doi.org/10.15575/jtk.v2i2.1878

Hastjarjo, T. D. (2019). Rancangan eksperimenkuasi. Buletin Psikologi, 27(2), 187-203. https://doi.org/10.22146/buletinpsikolo gi.38619

Hiatt, M. A. (2016). An Assessment of the effects of spiritual and relational teaching on student learning. Provo: Brigham Young University.

Imaduddin, M. (2019). Infusing islamic values and sustainable development into chemistry for pre-service islamic elementary school teachers. Jurnal Pendidikan Sains, 7(1), 47-54. https://doi.org/10.26714/jps.7.1.2019.47 $-54$

International Baccalaureate. (2020). Online learning, teaching and education continuity planning for schools. Wales: International

Baccalaureate Organization.

Januarti, R., Asrori, A., \& Jamiah, Y. (2017). Implementasi penilaian sikap spiritual dalam pembelajaran tematik di kelas IV Sekolah Dasar Islam Al-Azhar 21. Jurnal Pendidikan dan Pembelajaran Khatulistiwa, 6(12). Retrieved from https://jurnal.untan.ac.id/index.php/jpd pb/article/view/23196

Johan, H., Suhandni, A., Wulan, A.R., \& Sipriyadi. (2017). Grid Analysis Display System (GrADS) and multi modus visualization in earth science learning mastery and spiritual aspect to enhance concept. Journal of Turkish Science Education, 15(1), 109-127. Retrieved from

http://www.tused.org/index.php/tused/ article/view/152

Kemdikbud. (2014). Panduan penilaian pencapaian kompetensi peserta didik sekolah menengah pertama. Jakarta: Kementrian Pendidikan dan Kebudayaan.

Kuswana, D., Qomarruzzaman, B., \& Mahatma, M. (2020). Agama dan wabah (tanggapan ulama Jawa Barat atas Covid-19 Tahun 2020). Bandung: UIN Sunan Gunung Djati.

Narine, L. \& Meier, C. (2020). Responding in a time of crisis: assessing extension efforts during Covid-19. Advancements in Agricultural Development, 1(2), 12-23. https://doi.org/10.37433/aad.v1i2.35

Nasir, M., Mulyono, Y., \& Nastiti, L. R. (2020). Reconstructing distinction pattern of science education curriculum in Indonesian Islamic universities: An integrated paradigm for science and religion. Journal of Turkish Science Education, 17(1), 11-21. Retrieved from https://eric.ed.gov/?id=EJ1264727

Pitasari, R. \& Yunaningsih, A. (2016). Peningkatan keterampilan generik sains siswa melalui task based learning pada larutan buffer. JTK: Jurnal Tadris Kimiya, 1(1), 1-7. https://doi.org/10.15575/jta.v1i1.1161

Purwanto, A., Pramono, R., Asbari, M., Hyun, C. C., Wijayanti, L. M., \& Putri, R. S. (2020). Studi eksploratif dampak pandemi Covid-19 terhadap proses pembelajaran 
Students Learning Outcomes and Internalization Islamic Values in Buffer Solution Concept through Online Learning

online di sekolah dasar. EduPsyCouns: Journal of Education, Psychology and Counseling, 2(1), 1-12. Retrieved from https://ummaspul.ejournal.id/Edupsycouns/article/view/39 7

Saebani, B. A. (2020). Kesadaran teologis keberagamaan umat manusia menghadapi wabah Covid-19. Bandung: UIN Sunan Gunung Djati.

Saidah, K. \& Damariswara, R. (2017). Analisis bentuk bentuk penilaian sikap siswa sekolah dasar di Kota Kediri. Profesi Pendidikan Dasar, 4(1), 84-96. Retrieved from

http://journals.ums.ac.id/index.php/ppd /article/view/4244

Sandars, J., et al. (2020). Twelve tips for rapidly migrating to online learningduring the Covid-19 pandemic. MedEdPublish, 9(1), 82.

https://doi.org/10.15694/mep.2020.000 082.1 .

Sari, S. A. \& Ulya, A. (2017). The development of pop-up book on the role of buffer in the living body. European Journal of Social Sciences Education and Research, 4(4), 213-221. Retrieved from https://journals.euser.org/index.php/ejs er/article/view/2430

Shadish, W. R., Cook, T. D., \& Campbell, D. T. (2002). Experimental and quasiexperimental designs for generalized causal inference. Boston: Houghton Mifflin Co.

Setiadi, I., \& Irhasyuarna, Y. (2017). Improvement of model student learning through the content of solutions guided discovery buffer. IOSR Journal of Research \& Method in Education (IOSRJRME), 7(1), 01-09. https://doi.org/10.9790/73880701050109

Siregar, H. S., Sugilar, H., Ukit, \& Hambali, H. (2020). Merekonstruksi alam dalam kajian sains dan agama: studi kasus pada masa pembatasan sosial berskala besar (PSBB) dampak Covid-19. Bandung: UIN Sunan Gunung Djati.

Subrahmanyam, K., Frison, E., \& Michikyan, M. (2020). The relation between face-toface and digital interactions and selfesteem: A daily diary study. Hum Behav \& Emerg Tech, 2, 116-127. https://doi.org/10.1002/hbe2.187

Sulastri, Rusman, \& Arifa, A. (2018). Pengembangan soal-soal kimia bermuatan nilai-nilai untuk memperkokoh karakter siswa SMA. JTK: Jurnal Tadris Kimiya, 3(2), 171-181. https://doi.org/10.15575/jtk.v3i2.3512

Thayer-Bacon, B. J. (2016). Teaching spirituality as ontology in public schools. Democracy \& Education, 25(1), 1-5. Retrieved from https://democracyeducationjournal.org/ home/vol25/iss1/13/

The World Bank Education Global Practice. (2020). Guidance Note: Remote Learning $\&$ Covid-19. (https://www.worldbank.org/en/topic/e dutech\#Covidedtech), accessed 5th May 2020.

Treagust, D. F., \& Chittleborough, G. (2001). Chemistry: A matter of understanding representations. In Subject-specific instructional methods and activities. Emerald Group Publishing Limited. https://doi.org/10.1016/S14793687(01)80029-8

UNESCO. (2020). Coronavirus impacts education.

(https://en.unesco.org/themes/educatio n-emergencies/coronavirus-schoolclosures), accessed 6th May 2020.

Viner, R. M., Russel, S. J., Croker, H., et al. (2020). School closure and management practices during coronavirus outbreaks including Covid-19: A rapid systematic review. Lancet Child Adolesc Health, 4, 
397-404.

https://doi.org/10.1016/S2352-

4642(20)30095-X

Wiguna, A. (2017). Upaya mengembangkan sikap spiritual dan sosial peserta didik berbasis psikologi positif di sekolah. AlASASIYYA: Journal Of Basic Education, 1(2),

Yang, J. C., \& Lin, Y. L. (2010). Development and evaluation of an interactive mobile learning environment with shared display groupware. Educational Technology \& Society, 13(1), 195-207. Retrieved from https://www.jstor.org/stable/pdf/jeduct echsoci.13.1.195.pdf

Yani, F. H., Mawardi, W., \& Rusiani, A. F. (2019). The effectiveness of using student worksheet based on guided inquiry toward the student learning outcames in buffer solution material. International Journal of Progressive Sciences and Technologies (IJPSAT), 15(2), 58-62. http://doi.org/10.52155/ijpsat.v15.2.104 7

Zhang, W., Wang, Y., Yang, L., \& Wang, C. (2020). Suspending classes without stopping learning: China's education emergency management policy in the Covid-19 outbreak. Journal of Risk and Financial Management, 13(55), 1-6. https://doi.org/10.3390/jrfm13030055

Zhou, L., Li, F., Wu, S., \& Zhou, M. (2020). "School's out, but class's on", the largest online education in the world today: Taking China's practical exploration during the Covid-19 epidemic prevention and control as an example. Best Evid Chin Edu, 4(2), 501-519. https://doi.org/10.2139/ssrn.3555520 